\title{
Distribution and abundance of the salmonid parasite Parvicapsula minibicornis (Myxozoa) in the Klamath River basin (Oregon-California, USA)
}

\author{
Jerri L. Bartholomew ${ }^{1, *}$, Stephen D. Atkinson ${ }^{1}$, Sascha L. Hallett ${ }^{1}$, \\ Christopher M. Zielinski ${ }^{1}$, J. Scott Foott ${ }^{2}$
} ${ }^{1}$ Center for Fish Disease Research, Department of Microbiology, Oregon State University, 220 Nash Hall, Corvallis,
Oregon 97331, USA

${ }^{2}$ US Fish and Wildlife Service, California-Nevada Fish Health Center, 24411 Coleman Hatchery Road, Anderson, California 96007, USA

\begin{abstract}
The distribution and abundance of the myxosporean parasite Parvicapsula minibicornis in the Klamath River mirrored that of Ceratomyxa shasta, with which it shares both its vertebrate and invertebrate host. Assay of fish held at sentinel sites and water samples collected from those sites showed that parasite prevalence was highest below Iron Gate dam, which is the barrier to anadromous salmon passage. Above this barrier parasite levels fluctuated, with the parasite detected in the free-flowing river reaches between reservoirs. This was consistent with infection prevalence in the polychaete host, Manayunkia speciosa, which was greater than $1 \%$ only in populations tested below Iron Gate dam. Although a low prevalence of infection was detected in juvenile out-migrant fish in the Trinity River, the tributaries tested did not appear to be a significant source of the parasite to the mainstem despite the presence of large numbers of infected adult salmon that migrate and spawn there. Rainbow trout became infected during sentinel exposure, which expands the host range for $P$. minibicornis and suggests that wild rainbow trout populations are a reservoir for infection, especially above Iron Gate dam. High parasite prevalence in the lower Klamath River is likely a combined effect of high spore input from heavily infected, spawned adult salmon and the proximity to dense populations of polychaetes.
\end{abstract}

KEY WORDS: Distribution · Abundance $\cdot$ Salmonid parasite $\cdot$ Parvicapsula minibicorni $\cdot$ Myxosporea Klamath River Basin

Resale or republication not permitted without written consent of the publisher

\section{INTRODUCTION}

The discovery that the freshwater polychaete Manayunkia speciosa serves as the invertebrate host for the myxosporeans Parvicapsula minibicornis (Bartholomew et al. 2006) and Ceratomyxa shasta (Bartholomew et al. 1997) provides an explanation for the overlapping geographic distribution of these salmonid parasites. $P$. minibicornis was originally described from adult and juvenile salmon from the Fraser River, British Columbia, Canada (Kent et al. 1997) and subsequently from the Columbia River basin, Washington/Oregon/Idaho, USA (Jones et al. 2004). More recently, the parasite was identified in juvenile salmon from the Klamath River (KR),
California, USA (Foott et al. 2004, Bartholomew et al. 2006). The presence and distribution of C. shasta has been well documented in each of these systems (Ching \& Munday 1984, Bartholomew et al. 1989, Hoffmaster et al. 1988, Hendrickson et al. 1989, Stocking et al. 2006).

Severe infections by both myxosporeans have been observed in juvenile Chinook salmon Oncorhynchus tshawytscha in the KR since 1995. Examination of archived samples provided evidence of Parvicapsula minibicornis infections in juvenile Chinook salmon collected in the early 1990s (Foott et al. 2004), but there is no information on the distribution of the parasite or how long it has been present in the system. Ceratomyxa shasta is present throughout the mainstem KR to 
the estuary, but absent in tributaries with the exception of the headwaters to Klamath Lake in the upper basin (Hendrickson et al. 1989, Stocking et al. 2006). Recent studies have also mapped the distribution of the invertebrate host, Manayunkia speciosa, in the river (Stocking \& Bartholomew 2007). However, it is not known if the distribution of $P$. minibicornis in the KR mirrors either that of C. shasta or its invertebrate host. The exclusion of migrating salmon from the upper portion of the KR system since the completion of Iron Gate dam in the early 1960s may have restricted the parasite to the lower river if its introduction was recent. Distribution may also be affected by the parasite's vertebrate host specificity. $P$. minibicornis has only been reported from anadromous salmonids, thus their exclusion from above the dams may have resulted in extinction of the parasite above these barriers.

The role of Parvicapsula minibicornis as a direct cause of mortality in juvenile Chinook salmon in the KR has not been determined, and there are no data on infection in adult salmon from the Klamath system. This is in contrast to what is known of the effects of $P$. minibicornis further north in the Fraser River, British Columbia, where certain stocks of sockeye salmon
Oncorhynchus nerka have suffered significant prespawn mortality associated with the infection (St. Hilaire et al. 2002, Jones et al. 2003). In these fish, severity of infection was affected by migration time and water temperature, with early migrating fish having higher vulnerability to infection as a result of longer holding times in the river before spawning.

Reexamination of samples collected during recent studies on the distribution and prevalence of Ceratomyха shasta in the Klamath system (Stocking et al. 2006) allowed us to address these data gaps and to determine the presence and relative abundance of Parvicapsula minibicornis throughout much of the KR basin. Additionally, samples from out-migrating juvenile and returning adult salmon provided an indication of the parasite's biological effects on KR salmon and steelhead Oncorhynchus mykiss. This data set, which includes measures of parasite abundance in fish, polychaetes, and water, enabled us to compare the distribution and abundance of 2 parasites that share both their vertebrate and invertebrate hosts. It also establishes baseline levels of the parasite throughout the river that can be used for comparison between years with different temperature and flow patterns.

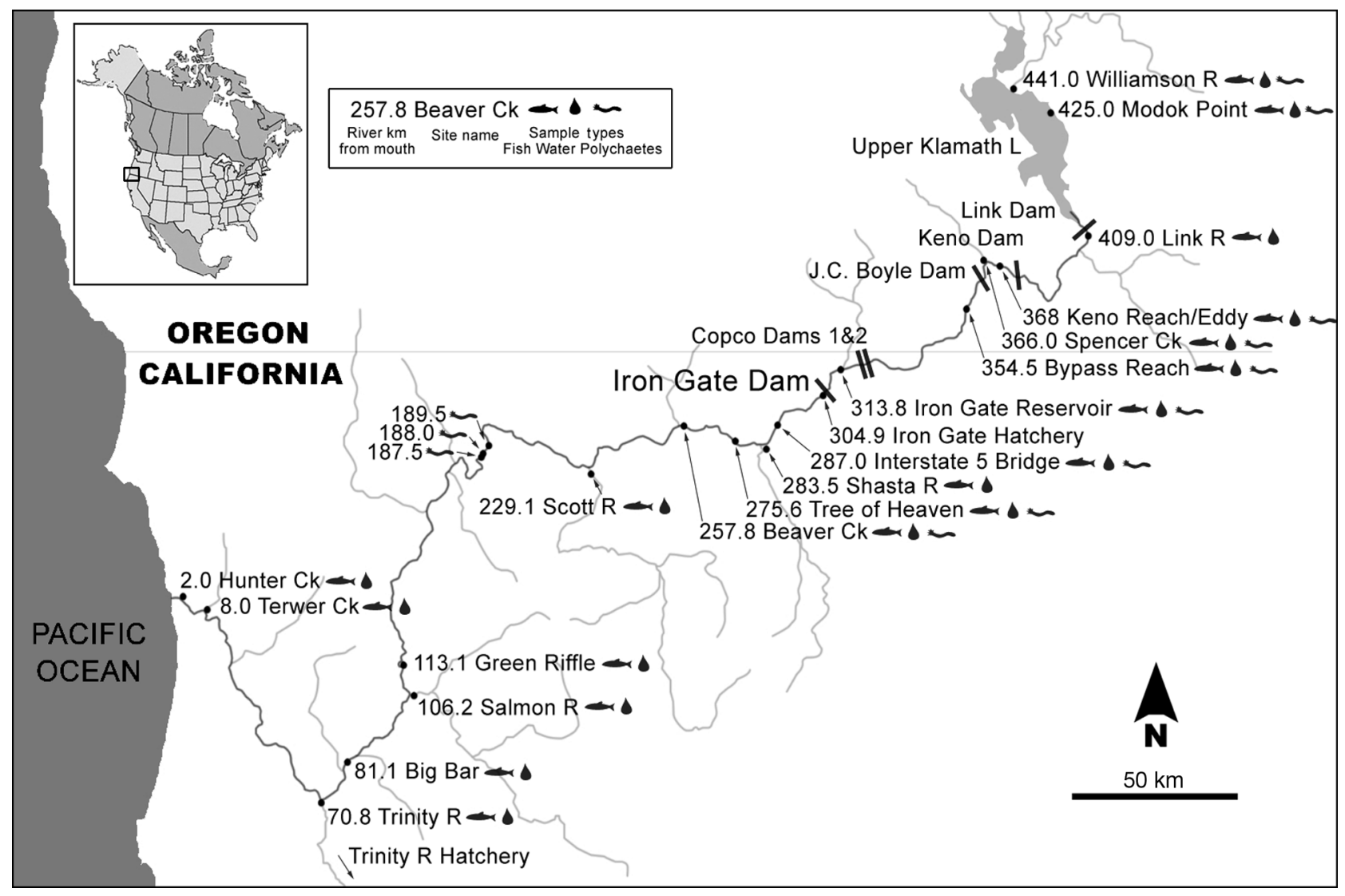

Fig. 1. Klamath River system showing dams, tributaries, hatcheries and sites where sentinel fish were exposed and water and polychaetes were sampled. Inset shows location of site in North America 


\section{MATERIALS AND METHODS}

Study area. The KR begins at Klamath Lake in south central Oregon (OR) and flows west-southwest to the northern California (CA) coast (Fig. 1). The river is approximately 425 river kilometers (Rkm) in length and for the purposes of this study, is divided into upper and lower reaches. The upper Klamath River (UKR), from Klamath Lake to Iron Gate dam, is approximately $120 \mathrm{Rkm}$ and characterized by a system of 5 dams. Iron Gate dam, the lowest dam in the system, is a barrier to anadromous fish passage. The lower Klamath River (LKR) extends nearly $306 \mathrm{Rkm}$ from that dam to the mouth of the river and receives input from several major tributaries, including the Trinity, Scott, Salmon and Shasta Rivers. Fig. 1 shows the locations of all sentinel fish exposure sites and collection sites for polychaetes and water samples.

Sentinel fish exposures. During June 2004, sentinel rainbow trout Oncorhynchus mykiss (Roaring River Hatchery, OR), were held for $4 \mathrm{~d}$ in cages at 18 locations throughout the KR to monitor for Ceratomyxa shasta presence (Fig. 1) (Stocking et al. 2006). Seventy fish were exposed at each location and monitored for $100 \mathrm{~d}$ post-exposure as described in Stocking et al. (2006). As a negative control, 70 fish were held on a specific pathogen-free water supply and sampled concurrently. The exposure group held at the Williamson River site in 2004 was lost as a result of vandalism, so an additional exposure was conducted in May 2005 using the same protocol. Additionally, in May 2005, 95 native redband rainbow trout Oncorhynchus mykiss ssp. were collected by rotary screw trap in Spencer Creek, a tributary of the UKR. Seventy of these fish were held in the KR mainstem near Beaver Creek alongside the hatchery rainbow trout, and 25 were retained as controls to determine if they were exposed to the parasites during rearing in Spencer Creek.

Samples for Ceratomyxa shasta assay had been taken from each fish at time of death or at $100 \mathrm{~d}$, and the remaining carcass was frozen at $-20^{\circ} \mathrm{C}$. For determination of Parvicapsula minibicornis infection, 25 fish from each group were thawed and a portion of the kidney excised. Total DNA was extracted using a DNeasy $^{\text {TM }}$ tissue kit (Qiagen) for assay by PCR. From groups where sufficient numbers survived to $100 \mathrm{~d}$, all 25 fish were sampled from the survivors. From groups where mortality from $C$. shasta was high, the fish that survived longest were sampled to insure there was sufficient time for replication of $P$. minibicornis in the kidney. There were no samples taken from the Klamath Lake or KR at Spencer Creek exposure groups.

Water collection. To quantify Parvicapsula minibicornis directly from river water and relate these spore loads to infection in fish, water samples were collected concurrently with the sentinel fish exposures (Fig. 1). Samples were collected approximately $30 \mathrm{~cm}$ below the water surface in a 21 clear plastic bottle and kept cool until processed (within $24 \mathrm{~h}$ of collection). These were filtered (two 11 samples per site) and the DNA extracted following the methods of Hallett \& Bartholomew (2006).

Adult salmon sampling. Kidney samples from adult KR Chinook and coho (Oncorhynchus kisutch) salmon and steelhead were collected by CA Department of Fish and Game personnel at the 2 hatcheries in the KR basin during winter 2005-2006 and 2006-2007 (Table 1). Iron Gate Hatchery (IGH) is located on Bogus Creek, a small tributary just below Iron Gate dam, but receives water directly from the reservoir. Trinity River Hatchery (TRH) is located on the Trinity River, a tributary of the LKR. Numbers of fish exam-

Table 1. Parvicapsula minibicornis infection prevalence and severity in adult salmonids returning to Iron Gate and Trinity River Hatcheries determined by PCR assay $(\%$ PCR + ) and assessment of kidney sections $(\%$ Histo +$)$. nd = assay not done

\begin{tabular}{|c|c|c|c|c|c|c|}
\hline \multirow{2}{*}{$\begin{array}{l}\text { Hatchery } \\
\text { Species }\end{array}$} & \multirow{2}{*}{ No. of fish } & \multirow{2}{*}{$\begin{array}{c}2005-2006 \\
\% \text { PCR + }\end{array}$} & \multirow{2}{*}{$\overline{\% \text { Histo + }}$} & \multirow[b]{2}{*}{ No. of fish } & \multirow{2}{*}{$\begin{array}{c}2006-2007 \\
\% \text { PCR + }\end{array}$} & \multirow[b]{2}{*}{$\%$ Histo + } \\
\hline & & & & & & \\
\hline \multicolumn{7}{|l|}{ Iron Gate } \\
\hline Fall Chinook salmon & 20 & nd & $90^{\mathrm{a}}$ & 20 & 100 & nd \\
\hline Coho salmon & 3 & 100 & nd & 20 & 55 & nd \\
\hline Steelhead & 10 & 100 & $40^{\mathrm{b}}$ & nd & nd & nd \\
\hline \multicolumn{7}{|l|}{ Trinity River } \\
\hline Spring Chinook salmon & nd & nd & nd & 19 & 100 & nd \\
\hline Fall Chinook salmon & 19 & 100 & $100^{c}$ & 20 & 100 & nd \\
\hline Coho salmon & 19 & 47 & nd & 20 & 80 & nd \\
\hline Steelhead & 20 & 95 & $80^{\mathrm{d}}$ & 20 & 90 & nd \\
\hline \multicolumn{7}{|c|}{$\begin{array}{l}\text { a High parasite numbers in both glomeruli and tubules; no glomerulonephritis } \\
{ }^{\text {b} L o w ~ p a r a s i t e ~ n u m b e r s ; ~ e x c l u s i v e l y ~ i n ~ t u b u l e s ; ~ n o ~ g l o m e r u l o n e p h r i t i s ~} \\
\text { cModerate glomerulonephritis in } 16 \% \text { of sections; high parasite numbers in } 47 \% \\
\text { d High parasite numbers in both glomeruli and tubules; no glomerulonephritis }\end{array}$} \\
\hline
\end{tabular}


ined varied, but we attempted to obtain 20 samples for each species and stock.

In 2005-2006, a portion of the kidney tissue from Chinook salmon and steelhead was fixed in Davidson's fixative for histology. Additionally, samples from these species and from coho salmon were fixed in $70 \%$ ethanol for PCR assay. In 2006-2007, samples were collected for PCR assay only.

Juvenile Chinook salmon sampling. During spring and early summer of each sample year (1992-2006;

Table 2. Incidence of Parvicapsula minibicornis infection $(\%$ Histo +$)$ and associated glomerulonephritis (\% GMN) in juvenile Chinook salmon collected between May and August 1992 to 2006 in the Klamath River Basin, as determined by examination of kidney sections

\begin{tabular}{|lcccc|}
\hline $\begin{array}{l}\text { Collection } \\
\text { location }\end{array}$ & Year & $\begin{array}{c}\text { No. of } \\
\text { fish }\end{array}$ & & \\
\hline Mainstem Klamath & 2005 & 132 & 92 & 70 \\
River & 2004 & 732 & 77 & 54 \\
& 2002 & 39 & 95 & 62 \\
& 1995 & 29 & 86 & 92 \\
Klamath Estuary & 1993 & 26 & 38 & 90 \\
& 2005 & 28 & 43 & 75 \\
& 2002 & 116 & 28 & 65 \\
& 2001 & 43 & 84 & 61 \\
Lower Trinity & 1997 & 90 & 68 & 75 \\
River & 1993 & 16 & 80 & 77 \\
& 2005 & 40 & 0 & 0 \\
Shasta River & 2001 & 31 & 6 & 0 \\
Scott River & 1996 & 26 & 8 & 0 \\
& 1992 & 25 & 8 & 0 \\
& 2006 & 15 & 0 & 0 \\
& 2000 & 36 & 0 & 0 \\
& 2000 & 62 & 0 & 0 \\
\hline
\end{tabular}

Table 2), migrating juvenile KR Chinook salmon were sampled along their migration route. Fish were collected weekly either by rotary screw trap or beach seine from the mainstem KR (between Rkm 25.8 and 286.6) and by beach purse seine from the KR estuary. Each week, we attempted to sample 30 fish from each trap and 20 from each seine, but often catches were less. Several collections were made from the Shasta and Scott River tributaries near their confluence with the KR, and from the lower Trinity River (Rkm 71). Fish were euthanized in tricaine methanesulfonate (200 ppm) and kidney tissues were removed and immediately fixed in Davidson's fixative for histology.

Polychaete sampling. Polychaetes for determination of Parvicapsula minibicornis infection prevalence were collected as part of the survey for Ceratomyxa shasta infection described by Stocking \& Bartholomew (2007). Polychaetes from 7 populations in the UKR and 6 in the LKR were chosen to estimate infection prevalence (Fig. 1). Polychaetes were randomly sorted into pools of 5 to 50 worms each, in $1.5 \mathrm{ml}$ tubes (Table 3 ); individual worms were assayed where prevalence was obviously high. Over 1000 polychaetes were also examined individually, alive, compressed under a coverslip to identify overt infections and to obtain actinospores for infection experiments (Bartholomew et al. 2006).

Histological detection of Parvicapsula minibicornis in fish. Tissue was fixed in Davidson's fixative, then transferred to $70 \%$ ethanol after $24 \mathrm{~h}$, processed for $5 \mu \mathrm{m}$ paraffin sections and stained with hematoxylin and eosin (Humason 1979). Each slide was examined at both low $(40 \times)$ and high magnification (400x). $P$. minibicornis infections were rated as diseased (parasite stages and glomerulonephritis present in $>33 \%$ of the kidney section), infected (parasites present;

Table 3. Prevalence of Parvicapsula minibicornis within populations of Manayunkia speciosa worms collected from the Klamath River, October 2003 to July 2005, as determined by PCR assay of pooled worms. Rkm: river km (from mouth)

\begin{tabular}{|c|c|c|c|c|}
\hline Rkm & Date & $\begin{array}{l}\text { No. of pools } \times \text { no. of worms in pool } \\
\text { (no. of positive pools) }\end{array}$ & $\begin{array}{c}\text { Total } \\
\text { worms }\end{array}$ & $\begin{array}{l}\text { Calculated \% } \\
\text { prevalence }\end{array}$ \\
\hline 441.0 & Jul 2004 & $4 \times 50(1), 4 \times 25(0), 10 \times 10(1), 10 \times 5(0)$ & 450 & 0.5 \\
\hline 425.0 & Jul 2004 & $5 \times 10(0), 10 \times 5(0)$ & 100 & 0 \\
\hline 368.5 & Oct 2003 & $4 \times 50(0), 4 \times 25(0) 10 \times 10(0) 10 \times 5(0)$ & 450 & 0 \\
\hline 368.2 & Jul 2004 & $4 \times 50(0), 4 \times 25(0), 10 \times 10(0), 10 \times 5(0)$ & 450 & 0 \\
\hline 352.2 & Jul 2004 & $4 \times 50(0), 5 \times 20(0), 10 \times 10(0), 10 \times 5(0)$ & 510 & 0 \\
\hline 327.2 & Jul 2004 & $4 \times 25(0), 5 \times 20(0), 10 \times 10(0), 10 \times 20^{\mathrm{a}}(0)$ & 500 & 0 \\
\hline 289.8 & Jul 2005 & $4 \times 50(4), 5 \times 20(3), 8 \times 10(5), 1 \times 40^{\mathrm{a}}(0)$ & 420 & 7.8 \\
\hline 278.3 & Mar 2005 & $15 \times 10(5), 30 \times 5(7), 45 \times 1(0)$ & 345 & 3.9 \\
\hline 211.9 & Jul 2005 & $2 \times 50(0), 5 \times 20(0), 8 \times 10(1), 5 \times 5(0)$ & 305 & 0.3 \\
\hline 189.5 & Aug 2004 & $4 \times 50(0), 4 \times 25(0), 10 \times 10(0), 10 \times 5(0)$ & 450 & 0 \\
\hline 188.0 & Aug 2004 & $4 \times 50(0), 4 \times 25(0), 10 \times 10(0), 10 \times 5(0)$ & 450 & 0 \\
\hline 187.5 & Jul 2005 & $2 \times 50(0), 5 \times 20(0), 8 \times 10(0), 5 \times 5(0)$ & 305 & 0 \\
\hline
\end{tabular}


inflammation $<33 \%$ ) or uninfected (no P. minibicornis visible).

Molecular detection of Parvicapsula minibicornis infection. For fish kidney tissue, P. minibicornis was detected using the PCR assay described by St. Hilaire et al. (2002). Infections in samples of pooled polychaetes were also determined by this assay, with modifications described by Stocking \& Bartholomew (2007). Controls included known infected fish and polychaetes and uninfected fish tissues for the polychaete assay.

Infection prevalence in polychaete populations was estimated from the pool sizes, number tested and number positive using the online Ausvet-Pooled Prevalence Calculator (Sergeant 2004) following the link to 'variable pool sizes and perfect test'. Prevalence here is expressed as percentage of the population PCR-positive for Parvicapsula minibicornis infection.

DNA extracted from water samples was assayed using a QPCR assay for Parvicapsula minibicornis (Foott et al. 2007). One $\mu \mathrm{l}$ of each $120 \mu \mathrm{l}$ DNA eluate was used in a $20 \mu$ reaction. A separate assay to test for inhibition had a low concentration of Ceratomyxa shasta DNA added to each river water sample reaction and to an inhibition control that had molecular grade water instead of river water. Spiked samples that fluoresced later than the control were considered inhibited and their final cycle threshold $(\mathrm{Ct})$ values for $P$. minibicornis were adjusted (lowered) by this difference in fluorescence. Two samples from each site were assayed in duplicate and the $\mathrm{Ct}$ values averaged. For sites with 1 negative sample, the final $\mathrm{Ct}$ value was increased by 1 unit (i.e. halved the measured DNA concentration). For sites with 2 negative samples, a $\mathrm{Ct}$ of 42 was designated.

\section{RESULTS}

\section{Parvicapsula minibicornis distribution}

\section{Sentinel fish}

Infection by Parvicapsula minibicornis was detected in sentinel fish held at locations throughout the mainstem KR (Fig. 2). Infection prevalence in groups at UKR sites ranged from 0 to $88 \%$. Infection in the LKR ranged from 40 to $84 \%$. The native redband rainbow trout held in the mainstem near Beaver Creek all became infected. Fish held in tributaries were negative for infection with the exception of a single fish (i.e. $4 \%$ prevalence) in Trinity River. All control fish were negative for $P$. minibicornis infection, as were the wildcaught redband rainbow trout before exposure near Beaver Creek.
Water

In general, detection of parasites in water samples paralleled that of detection in fish (Fig. 2). Where infection in fish was undetected or low (all tributaries, and in the reservoirs behind Iron Gate, Keno, Boyle and Link River dams), parasite levels in water were low or undetected $(\mathrm{Ct}>38)$. In the UKR, detection was highest at the Boyle bypass reach $(\mathrm{Ct}=34.9)$, where infection prevalence in fish was also greatest (88\%). Parasite levels were higher in water samples from all sites in the LKR compared with the UKR (up to 100-fold more parasite DNA than the highest UKR site). In the LKR, parasite levels were highest near Beaver Creek $(\mathrm{Ct}=27.9)$, where infection prevalence in fish was $84 \%$, then decreased progressively downstream.

\section{Polychaetes}

Parvicapsula minibicornis was only detected in 1 population of UKR polychaetes: Williamson River. Three polychaete populations sampled from the LKR were positive, with the highest infection prevalence occurring in populations collected between Iron Gate dam and the Shasta River confluence (Table 3, Fig. 2).

\section{Infection in adult salmon}

PCR analysis of kidney tissues from adult fish in 2005-2006 (Table 1) demonstrated greater than 90\% prevalence of Parvicapsula minibicornis in Chinook and coho salmon and steelhead returning to both hatcheries, except for coho salmon returning to $\mathrm{TRH}$, of which only $47 \%$ were infected. Histologically, there were differences in the presentation of infection between fall Chinook salmon and steelhead (coho salmon were not examined). In general, higher numbers of parasite presporogonic stages and fewer mature myxospores were observed in the kidney tubules of adult steelhead than Chinook salmon (Figs. 3 \& 4).

PCR assay of samples collected in 2006-2007 (Table 2) again demonstrated high infection prevalence in steelhead and in fall and spring Chinook salmon at both hatcheries. In contrast to the previous year, infection prevalence was higher among coho salmon collected at TRH (80\%) than IGH (55\%).

\section{Infection in juvenile out-migrant Chinook salmon}

Parvicapsula minibicornis was detected from kidney tissues of Chinook salmon smolts in the KR mainstem 


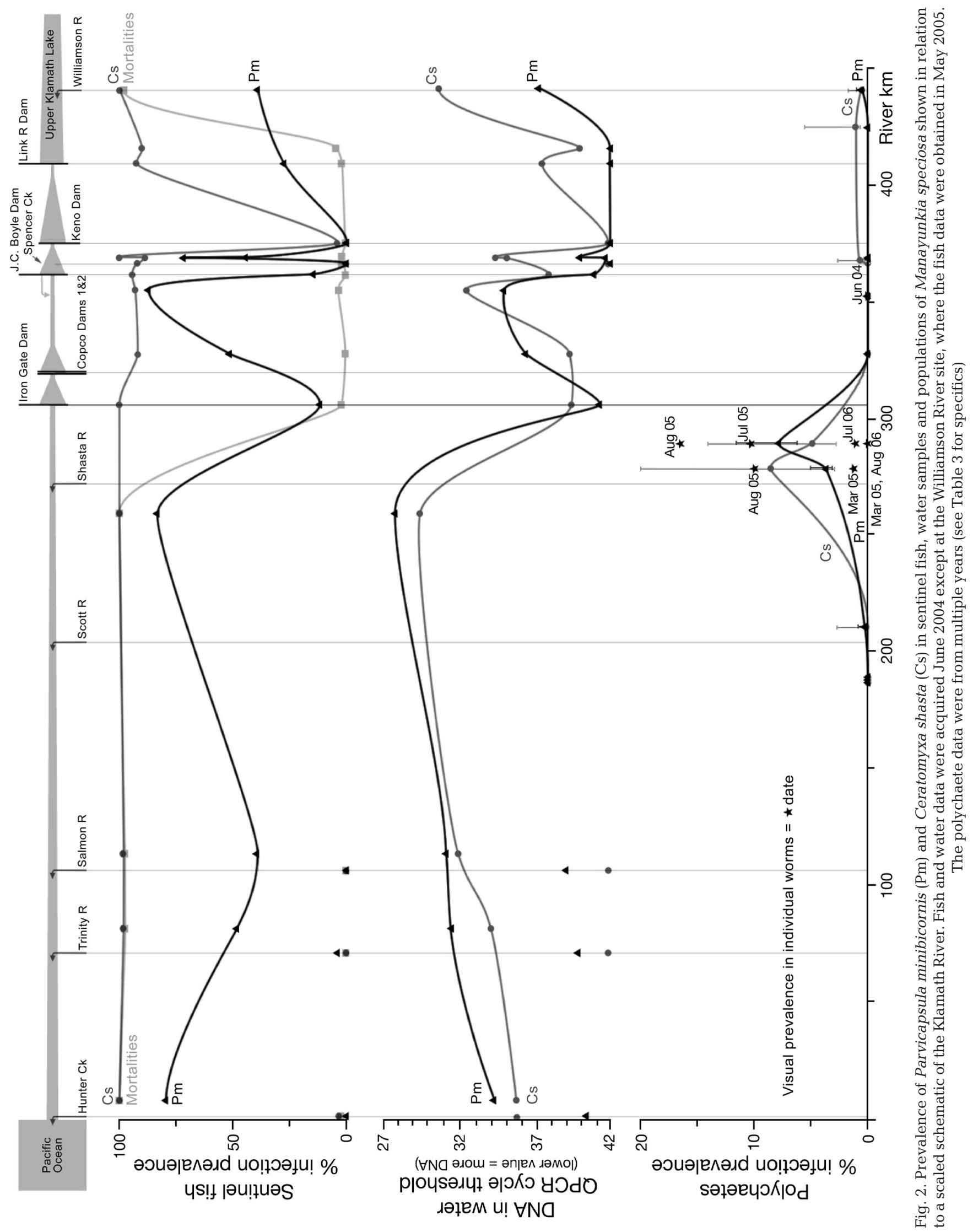




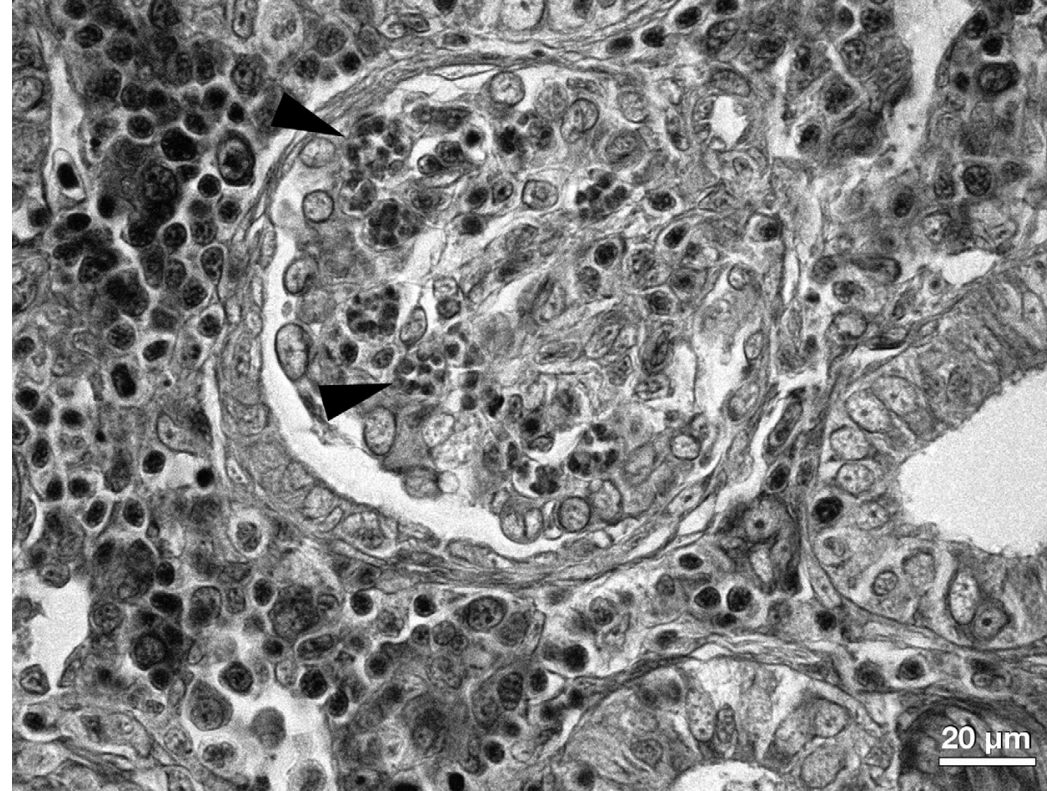

Fig. 3. Oncorhynchus tshawytscha. Hematoxylin and eosin stained thin section of kidney from an adult Chinook salmon with a moderate degree of glomerulonephritis, showing Parvicapsula minibicornis pre-sporogonic stages (arrowheads) in the glomeruli

and estuary in every study year since 1993 (Table 2). Infection prevalence varied between years, although direct comparison is not possible as the origin and residence time of these fish in the river is unknown. Fish captured in the mainstem KR in late June and July had multifocal glomerulonephritis (40 to $50 \%$ prevalence) and significant interstitial hyperplasia. In contrast, some smolts in the KR estuary showed histological signs of recovery such as increased numbers of regenerative basophilic nephrons and resolving granulomas surrounding the regions of glomerulonephritis. In some cases, the extent of tissue reactions masked parasite detection, and because these fish were not assayed by PCR, this resulted in a lower estimate of infection prevalence.

Among groups collected in tributaries, infection in Trinity River fish was low (0 to $8 \%$ prevalence) and none showed clinical disease signs. Infection was not detected in the limited samples of fish from the Shasta and Scott River tributaries. Gross kidney swelling was observed in 40 to $50 \%$ of Chinook salmon smolts in the mainstem in late June and July.

\section{DISCUSSION}

Parvicapsula minibicornis is widely distributed in the KR basin, with a distribution mirroring that of Ceratomyxa shasta (Stocking et al. 2006). For both parasites, infections in fish were more prevalent and more severe in the LKR than the UKR. However, one location, the Boyle bypass reach, appears to be a source for significant numbers of both parasites. The presence of $P$. minibicornis above Iron Gate dam indicates that incursion by the parasite is not recent, and the high infection prevalence among exposed redband rainbow trout suggests that the life cycle is likely maintained in the UKR by these native trout. LKR tributaries did not support the life cycle of $P$. minibicornis to the same extent as the mainstem, with detection only in a single sentinel rainbow trout and single juvenile Chinook salmon in the lower Trinity River. However, both parasites are established in the Williamson River, which serves as a headwater to the system.

Water sample data supported Parvicapsula minibicornis distribution in the sentinel fish, with increased levels of parasite DNA detected in the LKR. This pattern closely parallels that for Ceratomyxa shasta (Hallett \& Bartholomew 2006; our Fig. 2). However, for both parasites, abundance in water samples did not always reflect infection prevalence in fish. For P. minibicornis, infection prevalence at Keno Reach, Green Riffle and Big Bar was 44, 40 and 48\%, respectively, yet $\mathrm{Ct}$ values for water samples taken from these sites were 39.9, 31.2 and 31.6. Similarly, infection prevalence in fish held at Beaver Creek and Terwer was 83 and $80 \%$, respectively, yet $\mathrm{Ct}$ values were 27.9 and 34.2. This discrepancy could be because the QPCR assay detects both parasite spore stages, while infection in fish only reflects presence of the actinospore stage. This may result in sporadic detection of $P$. minibicornis in water from sites where fish did not become infected. The presence of more myxospores in water is likely in tributaries, where infected adult fish migrate but where there is limited habitat for polychaetes. Alternatively, parasite abundance in water was determined from two 11 samples taken at one time, while fish were exposed for $4 \mathrm{~d}$. Hence, water samples represent a snapshot of parasite abundance in contrast to sentinel fish which effectively serve as a biological filter of many kilolitres over 4 d. However, Foott et al. (2007) did find a correlation between parasite DNA in water samples and infection in Chinook salmon (versus rainbow trout), which may reflect interspecific host differences to infection. 

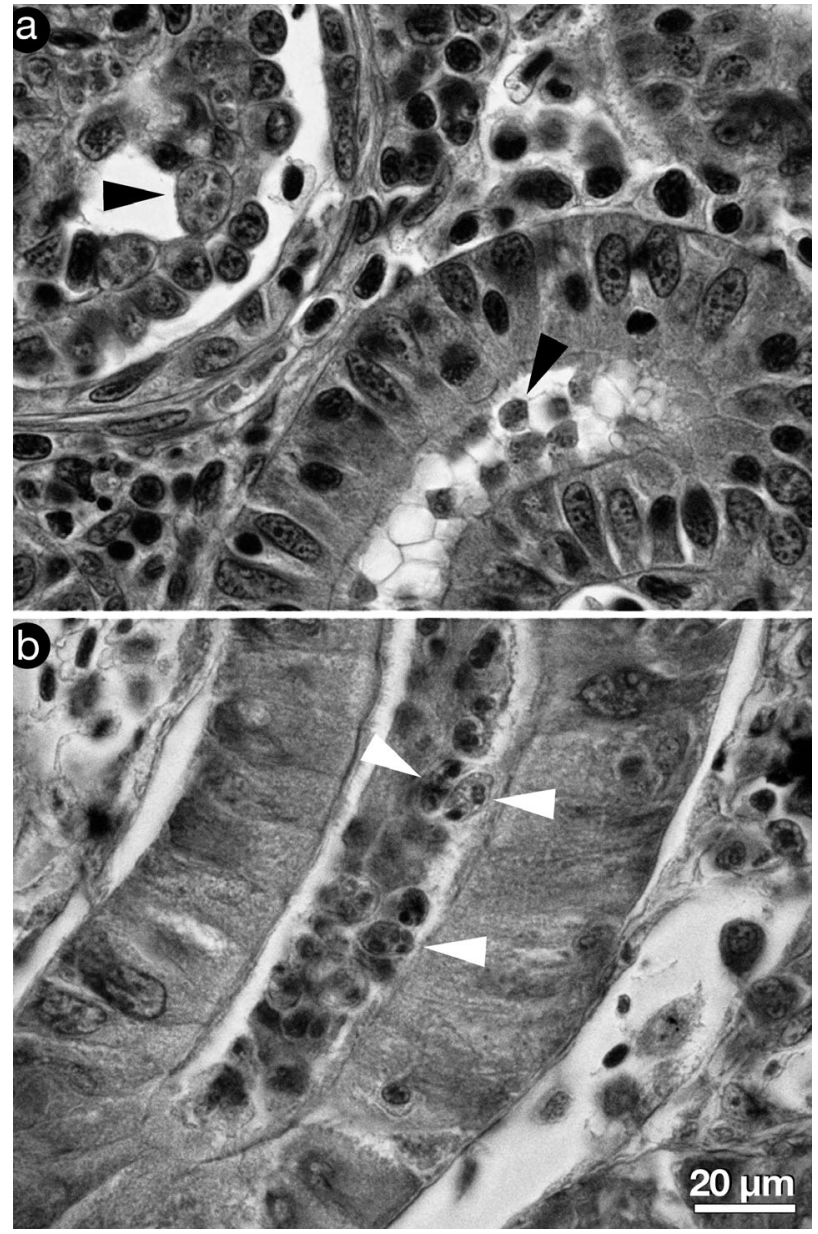

Fig. 4. Oncorhynchus mykiss. Hematoxylin and eosin stained thin section of kidney from an adult steelhead infected with Parvicapsula minibicornis. (a) Presporogonic stages (black arrowheads); mature myxospores (white arrowheads) in the kidney tubules

Infection prevalence in polychaete populations provides some explanation for the observed distribution in water. Populations collected 10 to $22 \mathrm{Rkm}$ downriver from Iron Gate dam had the highest infection rate of any LKR population. This is also an area were polychaete population densities are high and where Ceratomyxa shasta infection prevalence was greatest (Stocking \& Bartholomew 2007). Given that infected polychaetes may release thousands of actinospores (Bartholomew et al. 2006) that can survive at least $7 \mathrm{~d}$ (Foott et al. 2007), we expect these polychaete populations provide a high spore dose to fish throughout much of the unobstructed LKR. This is supported by the water sample data that shows parasite levels are highest near Beaver Creek and decrease downriver. However, the existence of other foci of infection is suggested by the increased incidence of infection in fish held just above the estuary.
Unlike Ceratomyxa shasta, the relationship between Parvicapsula minibicornis infection and survival of the various salmonid species has been difficult to determine. Examination of swimming performance of adult Fraser River (Canada) sockeye salmon demonstrated that heavily infected fish had a decreased ability to recover from exercise (Wagner et al. 2005). While this may be an indicator of osmoregulatory failure, the researchers were unable to detect a significant difference in plasma ion and osmolarity levels between infected and control fish. In the Klamath River system, 40 to $50 \%$ of Chinook salmon smolts collected in late June and July had observable gross kidney swelling. Yet, histological examination of out-migrating fish in the estuary indicated that these infections may resolve. Low numbers of parasites were also observed in the kidney tubules of asymptomatic fish that survived $48 \mathrm{~h}$ saltwater challenges (authors' unpubl. data). Hence, recovery appears possible if the parasite challenge is moderate and there are no concomitant infections. Smolts with dual infections of $C$. shasta and $P$. minibicornis would be expected to have lower survival.

Parvicapsula minibicornis infection prevalence was high in adult Chinook and coho salmon and steelhead returning to both hatcheries. The high infection prevalence and associated glomerulonephritis in Chinook salmon (both fall and spring runs) returning to $\mathrm{TRH}$ could indicate that (1) parasite abundance in the KR below the Trinity River confluence is high, (2) few parasites are required to cause infection, or (3) these fish spend a long period in the mainstem KR before migrating into the Trinity River. Infections in steelhead returning to TRH were less severe, but these were more prevalent and lesions more severe than in IGH steelhead. However, numbers of fish examined were low and it is unknown whether these fish were collected at the same point during migration. Migration times for each stock vary, with spring-run Chinook salmon entering the system in April to July followed by fall-run Chinook in late August and September; coho salmon and steelhead migrate later as water temperature drops below $10^{\circ} \mathrm{C}$ (National Research Council 2004). The parallel decrease in parasite abundance with water temperature in fall may explain the variability in infection prevalence seen in coho salmon. In the Fraser River, where P. minibicornis has been associated with prespawn mortality in late-run sockeye salmon (St. Hilaire et al. 2002), the ability to detect infections is related to accumulated thermal units of exposure (Wagner et al. 2005). Thus both temperature and timing of exposure affect the rate of disease.

Large numbers of adult Chinook salmon heavily infected with both Parvicapsula minibicornis and Ceratomyxa shasta (authors' pers. obs.) return to TRH and presumably provide a source of infection for any poly- 
chaete populations in that river. However, there were few detections of either parasite in water, sentinel fish, or Chinook salmon smolts in the lower Trinity River. This suggests that conditions for establishment of the life cycles are unfavorable compared with the mainstem KR, likely due to the lack of polychaete habitat. Lower water temperatures in the Trinity River may also retard parasite development. A similar scenario has been noted in the Deschutes River system (central Oregon), where the mainstem and one major tributary, the Crooked River, have high levels of C. shasta, yet fish do not become infected in another large, but cooler, tributary, the Metolius River (Ratliff 1983).

In contrast to $\mathrm{TRH}$, the large numbers of infected adult salmon and steelhead that return to spawn at IGH likely result in the high infection prevalence of both myxosporeans in dense polychaete populations immediately downriver. However, what drives the parasite life cycles in the UKR is unknown. Both myxosporeans are absent or in low abundance in the reservoirs due to a lack of polychaete habitat (Stocking \& Bartholomew 2007). In the free-flowing stretches of river between the reservoirs, parasite abundance increases. This can be explained, in part, by populations of polychaetes that occur in the moderate flows of eddies and pools. In the UKR polychaete populations we tested, infection prevalence for both Parvicapsula minibicornis and Ceratomyxa shasta was $1 \%$ or less, which likely represents a level that sustains the life cycle without resulting in high morbidity or mortality of juvenile fish. However, there are sections of the UKR, such as the Williamson River inflow into Klamath Lake and the Boyle bypass reach, that have consistently shown high levels of both parasites in sentinel fish and water samples. The source of infectious spores for the polychaetes is likely resident redband rainbow trout populations.

The similar distribution and abundance of Parvicapsula minibicornis and Ceratomyxa shasta in the KR basin reflects the fact that these parasites share both invertebrate and vertebrate hosts. It also demonstrates that $P$. minibicornis has been a long-time resident of this system, certainly present prior to construction of the dams and reservoirs. Thus, changes that have occurred in the $\mathrm{KR}$, both as a result of natural and human causes, affect both parasites similarly.

Acknowledgements. S. Corum, Karuk Tribal Fisheries program, assisted with the collection of water samples; R. Turner and P. Zedonis, USFWS-Arcata, CA, provided equipment, advice, and field assistance. California Department of Fish and Game fish pathologists supplied samples from adult salmon. Fish for the sentinel studies were supplied by the Oregon Department of Fish and Wildlife (ODFW). B. Tinniswood, ODFW, collected the redband rainbow trout. R. Stocking and R. Holt collected water and polychaete samples and conducted the original sentinel studies. H. Lorz and L. Osborn assisted with necropsy and sample collection from fish. G. Cobarrubias and M. Wahnsiedler conducted the PCR assays. The Central Service Laboratory in the Center for Gene Research and Biotechnology, OSU, provided the QPCR machine (ABI Prism 7000 sequence detection system), NanoDrop Spectrophotometer and the Capillary Genetic Analyzer. This publication was partially supported by the National Sea Grant College Program of the US Department of Commerce's National Oceanic and Atmospheric Administration under NOAA Grant \# NA16RG1039 (project no. R/RCF-15) and by appropriations made by the Oregon State legislature. The views expressed herein do not necessarily reflect the views of any of those organizations. Support was also provided by the US Fish and Wildlife Service, via the Klamath River Basin Fisheries Task Force, the Karuk Tribal Fisheries Program, PacifiCorp and through undergraduate research fellowships from the Howard Hughes Medical Institute and Oregon Sea Grant Extension.

\section{LITERATURE CITED}

Bartholomew JL, Rohovec JS, Fryer JL (1989) Ceratomyxa shasta, a myxosporean parasite of salmonids. US Fish and Wildlife Service, Fish Disease Leaflet 80. www.lsc. usgs.gov/FHB/leaflets/80.asp

Bartholomew JL, Whipple MJ, Stevens DG, Fryer JL (1997) The life cycle of Ceratomyxa shasta, a myxosporean parasite of salmonids, requires a freshwater polychaete as an alternate host. J Parasitol 83:859-868

Bartholomew JL, Atkinson SD, Hallett SL (2006) Involvement of Manayunkia speciosa (Annelida: Polychaeta: Sabellidae) in the life cycle of Parvicapsula minibicornis, a myxozoan parasite of Pacific salmon. J Parasitol 92:742-748

Ching HL, Munday DR (1984) Geographic and seasonal distribution of the infectious stage of Ceratomyxa shasta Noble, 1950, a myxozoan salmonid pathogen in the Fraser River system. Can J Zool 62:1423-1424

Foott JS, Harmon R, Stone R (2004) Effect of water temperature on nonspecific immune function and ceratomyxosis in juvenile Chinook salmon and steelhead from the Klamath River. Calif Fish Game 90:71-84

Foott JS, Stone R, Wiseman E, True K, Nichols K (2007) Longevity of Ceratomyxa shasta and Parvicapsula minibicornis actinospore infectivity in the Klamath River. J Aquat Anim Health 19:77-83

Hallett SL, Bartholomew JL (2006) Application of a real-time PCR assay to detect and quantify the myxozoan parasite Ceratomyxa shasta in water samples. Dis Aquat Org 71:109-118

Hendrickson GL, Carleton A, Manzer D (1989) Geographic and seasonal distribution of the infective stage of Ceratomyxa shasta (Myxozoa) in northern California. Dis Aquat Org 7:165-169

Hoffmaster JL, Sanders JE, Rohovec JS, Fryer JL, Stevens DG (1988) Geographic and seasonal distribution of the myxosporean parasite, Ceratomyxa shasta Noble, 1950, in the Columbia River basin, USA. J Fish Dis 11:97-100

Humason GL (1979) Animal tissue techniques. WH Freeman, San Francisco, CA

Jones SRM, Prosperi-Porta G, Dawe SC, Barnes DP (2003) Distribution, prevalence, and severity of Parvicapsula minibicornis infections among anadromous salmonids in the Fraser River, British Columbia, Canada. Dis Aquat Org 54:49-52

Jones S, Prosperi-Porta G, Dawe S, Taylor K, Goh B (2004) 
Parvicapsula minibicornis in anadromous sockeye (Oncorhynchus nerka) and coho (Oncorhynchus kisutch) salmon from tributaries of the Columbia River. J Parasitol 90:882-885

Kent ML, Whitaker DJ, Dawe SC (1997) Parvicapsula minibicornis n. sp. (Myxozoa, Myxosporea) from the kidney of sockeye salmon (Oncorhynchus nerka) from British Columbia, Canada. J Parasitol 83:1153-1156

National Research Council (2004) Endangered and threatened fishes in the Klamath River Basin: causes of decline and strategies for recovery. National Academic Press, Washington, DC

Ratliff DE (1983) Ceratomyxa shasta: longevity, distribution, timing, and abundance of the infective stage in central Oregon. Can J Fish Aquat Sci 40:1622-1632

Sergeant E (2004) Pooled prevalence calculator. AusVet Animal Health Services. www.ausvet.com.au/pprev/

Editorial responsibility: David Marcogliese, Montréal, Quebec, Canada
St. Hilaire S, Boichuk M, Barnes D, Higgins M and others (2002) Epizootiology of Parvicapsula minibicornis in Fraser River sockeye salmon, Oncorhynchus nerka (Walbaum). J Fish Dis 25:107-120

Stocking RW, Bartholomew JL (2007) Distribution and habitat characteristics of Manayunkia speciosa and infection prevalence with the parasite, Ceratomyxa shasta, in the Klamath River, OR-CA, USA. J Parasitol 93:78-88

Stocking RW, Holt RA, Foott JS, Bartholomew JL (2006) Spatial and temporal occurrence of the salmonid parasite Ceratomyxa shasta (Myxozoa) in the Oregon-California Klamath River Basin. J Aquat Anim Health 18:194-202

Wagner GN, Hinch SG, Kuchel LJ, Lotto A and others (2005) Metabolic rates and swimming performance of adult Fraser River sockeye salmon (Oncorhynchus nerka) after a controlled infection with Parvicapsula minibicornis. Can J Fish Aquat Sci 62:2124-2133

Submitted: August 18, 2007; Accepted: October 26, 2007 Proofs received from author(s): December 5, 2007 